\title{
Demographics of a heavily exploited deep water shark Echinorhinus cf. brucus (Bonnaterre, 1788) from the south-eastern Arabian Sea
}

\author{
K. V. AKHILESH, C. ANULEKSHMI, K. K. BINEESH, U. GANGA AND N. G. K. PILLAI \\ ICAR-Central Marine Fisheries Research Institute, Kochi - 682 018, Kerala, India \\ e-mail:akhikv@gmail.com
}

\begin{abstract}
In the absence of direct consumption importance and considering as low value bycatch, many vulnerable non-target species, especially slow growing deep water fauna, are overlooked in tropical fisheries research and management. The bramble shark Echinorhinus cf. brucus (Bonnaterre, 1788) is one such species, subjected to a significant non-targeted deepwater fishery off southern India. A length frequency based stock assessment of bramble shark caught in trawl fisheries from the south-eastern Arabian Sea suggests that, $E$. cf. brucus is a moderately slow growing $\left(\mathrm{K}=0.12\right.$ year $\left.^{-1}\right)$ and moderately long lived shark species $\left(\mathrm{T}_{\max }=25\right.$ years, $\mathrm{L}_{=}=333$ at corresponding age of 55 years) which is overexploited $(\mathrm{M}=0.17, \mathrm{Z}=0.39)$ in the region. In view of resilience capacity and vulnerability of deep sea fisheries, improved research and monitoring programmes are urgently required to ensure a sustainable future for India's expanding deep sea and distant water fisheries.
\end{abstract}

Keywords: Bycatch, Deep sea, Indian Ocean, India, Population dynamics, Shark fishery, Sustainability

\section{Introduction}

Deep sea chondrichthyans are highly vulnerable to overexploitation due to their unique life history and biologicaltraits(Hutchings, 2002; Simpfendorferand Kyne, 2009). Information on exploitation, population dynamics, biology, ecology and distribution of most exploited deep water species are unavailable making fishery managers highly concerned about their sustainability and extinction risk (Graham et al., 2001; Clarke et al., 2003; Garcia et al., 2008 ; Kyne and Simpfendorfer, 2007, 2010), especially in the wake of shark declines in many of the world's marine waters (Dulvy and Forrest, 2010; Worm et al., 2013; Dulvy et al., 2014). However, knowledge gaps on many elasmobranchs especially deep sea shark fauna and rare species are quite high from Indian Ocean region mostly due to lack of research effort and geographic/ habitat range bias (Ducatez, 2019). Conservation and management of deep sea shark fauna in Indian Ocean or elsewhere is often limited by lack of information on catch, stock, effort and biology.

The bramble shark Echinorhinus cf. brucus (Bonnaterre, 1788) a poorly known deepwater shark, with a reported maximum size $\left(\mathrm{L}_{\max }\right)$ of $318 \mathrm{~cm} \mathrm{TL}$, occurring mostly at 200-1200 m depths and occasionally in shallow waters, from the Gulf of Aden to the Sea of Oman, Pakistan, India, Maldives, Sri Lanka, Bay of Bengal and Andaman Sea, in the northern Indian Ocean (Naylor et al., 2012; Akhilesh et al., 2013; Henderson et al., 2016; Kumar et al., 2018; Fernando et al., 2019).
Along the southern coasts of India, where the continental shelf is narrow and fishing occurs in deepwater, E. cf. brucus occurs mainly as bycatch in various gears (mostly trawls) and since 2002 it has been a major bycatch in the gulper shark (Centrophorus spp.) longline fishery (Akhilesh et al., 2011, 2013). Elsewhere in the world, echinorhinid shark species are rarely caught in huge quantities possibly due to inaccessible fishery habitat (except in southern India). Hence no studies have been carried out either on the biology (Akhilesh et al., 2013), or the stock parameters of the members of Echinorhinidae, hindering the development of management strategies.

Most deep sea sharks from the Arabian Sea and the larger Indian Ocean region are assessed as Data Deficient (DD) in the IUCN Red List assessments, due to limited information on population status or trends (Jabado et al., 2017). In the Regional Red List assessment of chondrichthyan species occurring in the Arabian Sea and adjacent waters (ASR), Echinorhinus cf. brucus is assessed as Vulnerable (VU) (Jabado et al., 2018), due to the high fishing pressure in the region and Data Deficient (DD) in the global assessment (Paul, 2003). Global Red List assessments often underestimate the local population status when the species has restricted or patchy distribution/population range and regional fishing pressures are alarmingly high than expected or compared to elsewhere in the known distribution range. In this paper, we provide the first estimate on the demographics of the deep sea shark $E$. cf. brucus, from the Indian waters, which will help inform future management actions and update global and regional conservation assessments. 


\section{Materials and methods}

Length data (TL) of 3679 individuals of $E$. cf. brucus was collected from the trawl landings at Cochin Fisheries Harbour (Kerala), India during 2009-2011 (excluding the month of July due to the closed season). For each individual, the total length (measured from the anterior most part of the head with mouth closed to the farthest tip of the caudal fin upper lobe and recorded to nearest centimetre), weight and sex were recorded. Pooled length frequency data for the period 2009-11 were grouped into $10 \mathrm{~cm}$ intervals. Growth, mortality and exploitation levels were estimated from the length-frequency data using FiSAT II software (Gayanilo and Pauly, 1997; Gayanilo et al., 2005). Asymptotic length $\left(\mathrm{L}_{\infty}\right)$ and growth constant $(K)$ were further used to estimate other parameters. Based on $\mathrm{L}_{\infty}$ and $\mathrm{K}$, the growth performance index $(\varphi)$ and potential longevity $(3 / K)$ were determined (Munro and Pauly, 1983). Instantaneous total mortality ( $\mathrm{Z}$ ) was estimated from the length-converted catch curve (Pauly, 1984); natural mortality (M) was determined using Pauly's empirical formula (Pauly, 1980), with ambient temperature used as $15^{\circ} \mathrm{C}$ for the habitat; fishing mortality (F) was calculated as $\mathrm{F}=\mathrm{Z}-\mathrm{M}$ and exploitation rate $(\mathrm{E})$ as $\mathrm{E}=\mathrm{F} / \mathrm{Z}$. Lengthconverted catch curve was then used to determine the length at first capture $\left(\mathrm{L}_{\mathrm{c}}\right)$, Length-structured virtual population analysis (VPA) was performed (Pauly, 1984). Exploitation rates that retains $50 \%$ of the biomass $\left(\mathrm{E}_{50}\right)$ and maximum yield per recruit $\left(\mathrm{E}_{\text {max }}\right)$ were then predicted using relative yield per recruit $\left(\mathrm{YR}^{-1}\right)$ and relative biomass per recruit $\left(\mathrm{BR}^{-1}\right)$ analysis using knife-edge selection (Pauly, 1984).

\section{Results and discussion}

Fishery for E. cf. brucus in the south-west coast of India exploits all size classes in the stock. Asymptotic length $\left(\mathrm{L}_{\infty}\right)$ was estimated as $333 \mathrm{~cm}$ TL and growth coefficient $(\mathrm{K})$ was estimated at 0.12 year $^{-1}$ (Table 1), similar to those of other deep water chondrichthyans (Cortes, 2000). Comparative growth coefficient study of chondrichthyans (Cailliet, 1990; Cailliet and Goldman, 2004) suggest that a wide range of $K$ values $\left(0.034\right.$ year $^{-1}$ for Squalus acanthias (Ketchen, 1975), 0.05 year $^{-1}$ for Dipturus pullopunctata (Walmsley-Hart et al., 1999) and 1.3 year $^{-1}$ in Rhizoprionodon taylori (Simpfendorfer, 1993) can be used to interpret life history traits, with most deep sea chondrichthyans having a low $\mathrm{K}$ value like 0.12 year ${ }^{-1}$ for Squalus megalops (Avsar, 2001) and 0.0880.092 year $^{-1}$ for Alopias superciliosus (Liu et al., 1998). Based on the VBGF growth coefficient values (Fig. 1), E. cf. brucus in south-eastern Arabian Sea is considered to be a moderately slow growing species (Branstetter 1987; Branstetter and Musick, 1994). The values of $\mathrm{L}_{\infty}$ and $\mathrm{K}$ estimated by ELEFAN were considered for the calculation of lengths attained by E. cf. brucus at quarterly intervals using von Bertalanffy's growth formula. The total length attained by E. brucus were $150,233,278,303 \mathrm{~cm}$ at the end of $5,10,15,20$ years of its life span respectively and for the maximum size $\left(\mathrm{L}_{\max }\right)$ observed $318 \mathrm{~cm}$ TL the respective

Table 1. Growth, mortality and exploitation parameters of Echinorhinus cf. brucus from south-eastern Arabian Sea

\begin{tabular}{ll}
\hline Parameter & Value \\
\hline $\mathrm{L}_{\infty}$, Asymptotic length $(\mathrm{cm})$ & 333 \\
$\mathrm{~K}$, Growth coefficient $\left(\mathrm{y}^{-1}\right)$ & 0.12 \\
$\mathrm{t}_{\mathrm{o}}\left(\mathrm{y}^{-1}\right)$ & -0.06 \\
$\phi^{\prime}$, Growth performance index & 4.12 \\
$Z$, Total mortality $\left(\mathrm{y}^{-1}\right)$ & 0.39 \\
$\mathrm{M}$, Natural mortality $\left(\mathrm{y}^{-1}\right)$ at 13 & 0.17 \\
$\mathrm{~F}$, Fishing mortality $\left(\mathrm{y}^{-1}\right)$ & 0.22 \\
$\mathrm{E}$, Current exploitation rate & 0.56 \\
$\mathrm{E}_{\text {max }}$, Maximum yield per recruit & 0.39 \\
$\mathrm{~L}_{\mathrm{c}}$, Length at first capture $(\mathrm{cm})$ & 199 \\
\hline
\end{tabular}

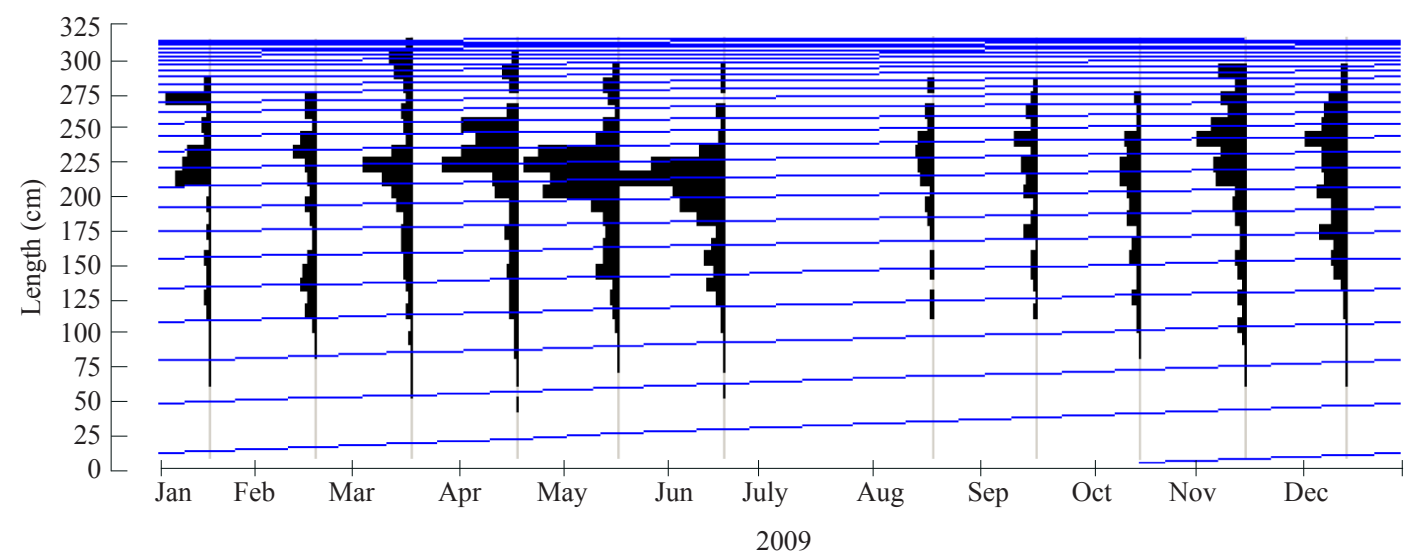

Fig. 1. von Bertalanffy growth curve drawn on restructured length-frequency data of Echinorhinus cf. brucus from south-eastern Arabian Sea, where positive points (black bars) are shown. The points were computed and used to identify the growth curve which passes through the largest number of positive points by avoiding negative points. $\left(\mathrm{L}_{\infty}=333 \mathrm{~cm}\right.$ and $\mathrm{K}=0.12$ year $\left.{ }^{-1}\right)$ 
age was 26 year and for attaining $\mathrm{L}_{\infty}$ the age would be 55 years. Age at maturity is $187-189 \mathrm{~cm}$ TL at 7 years. Following Pauly (1979), $\mathrm{t}_{0}$ was estimated as -0.06 year $^{-1}$.

The phi prime growth performance Index $(\Phi)$ which is one of the parameters that determines a relationship between $\mathrm{L}_{\infty}$ and $\mathrm{K}$, was estimated at 4.12. Most deep sea chondrichthyans have low natural mortality (M) due to low predation and high juvenile survival rate, butjl vulnerability to fishing gear will be very high if most individuals and all size class of population is vulnerable to fishing. The natural mortality coefficient, $\mathrm{M}(0.17)$ is similar to those obtained for other deep sea sharks like Etmopterus pusillus and E. spinax (0.17-0.26 year ${ }^{-1}$ and 0.21-0.42 year $^{-1}$ ) (Coelho and Erzini, 2005). For deep water species, it is desirable that the value of fishing mortality (F) as less or equal to $\mathrm{M}$ as a precautionary approach and even very low fishing mortality levels are enough to lead to overexploited state of deep sea sharks (Graham et al., 2001; Devine et al., 2006; Morato et al., 2006). The F value estimated (0.22) in this study is higher than $\mathrm{M}$, indicating increasing levels of exploitation of the species.

The exploitation rate $(\mathrm{E})$ and exploitation ratio (U) values were estimated as 0.56 and 0.40. Exploitation rate $(\mathrm{E})$ is slightly above the optimum value of $\mathrm{E}(0.5)$ suggesting evidences of overexploitation, supported by the observations of declining fishery (Akhilesh et al., 2013). In the present study, the knife-edge procedure gave $\mathrm{E}_{\text {max }}$ of 0.39 . As $\mathrm{E}$ is 0.56 , the fishery is considered as "over fished" (Gulland, 1971). It was observed that the gulper shark fishery in southern India declined due to unprofitability and high juvenile catch and this could be applicable to E. cf. brucus also. The higher E (0.56) compared to $\mathrm{E}_{\mathrm{m}}$ obtained in the study may perhaps be due to bycatch of all size classes in vessels operating in deeper waters. The population status can be estimated based on ratio of, $\mathrm{Z} / \mathrm{K}$ ie., $>1$ indicates that the population is mortality dominated and if less than 1 it is growth dominated (Pauly, 1984). However, the $\mathrm{Z} / \mathrm{K}$ of 3.25 estimated in the present study, indicates that the population is highly mortality (Fishing mortality) dominated.

The length at first capture $\left(\mathrm{L}_{\mathrm{c}}\right)$ in the present study is estimated at $199 \mathrm{~cm}$ TL (Fig. 2). Several researchers reported that sexual maturity in E. brucus occurs between 182 and $231 \mathrm{~cm} \mathrm{TL}$ in females and 150 and $187 \mathrm{~cm} \mathrm{TL}$ in males (Barrul and Mate, 1996; Compagno et al., 2005; Henderson et al., 2007; Akhilesh et al., 2013). However, the length at first capture in the present study $(199 \mathrm{~cm})$ falls within the broad maturity size range indicating, most of the members in the stock are not getting chance to support next recruitment. The ratio of $\mathrm{L}_{\mathrm{m}} / \mathrm{L}_{\infty}$ estimated as 0.57 for females and 0.56 for males, indicates that
E. cf. brucus is a moderate maturing species (Compagno, 1984; Liu et al., 2015). F for the species estimated based on length cohort analysis shows an increasing trend for the large size groups. The recruitment pattern of $E$. cf. brucus shows a continuous one with a single peak per year. The highest (17\%) and lowest (1\%) percent recruitment takes place in May and January (Fig. 3) respectively.

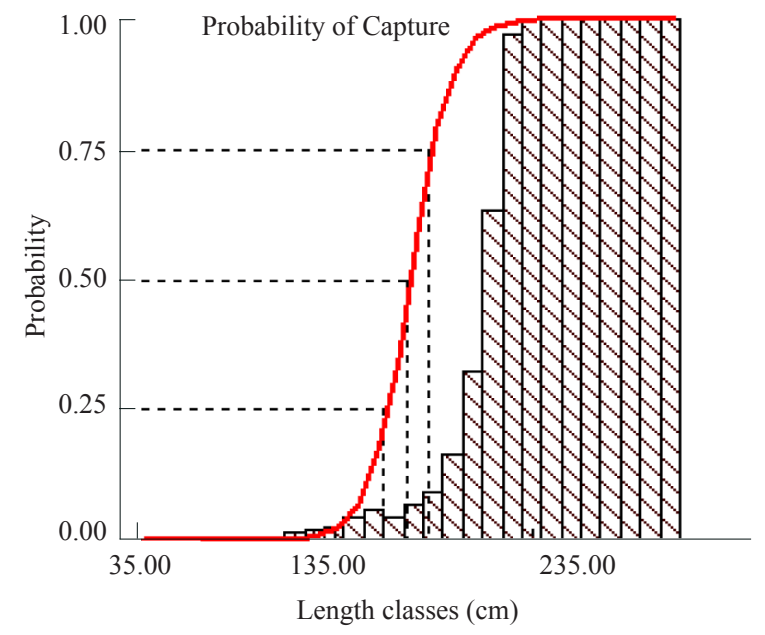

Fig. 2. Probability of length at capture of Echinorhinus cf. brucus from south-eastern Arabian Sea. $\mathrm{L}_{25}=183 \mathrm{~cm}$; $\mathrm{L}_{50}=199 \mathrm{~cm}, \mathrm{~L}_{75}=216 \mathrm{~cm}$.

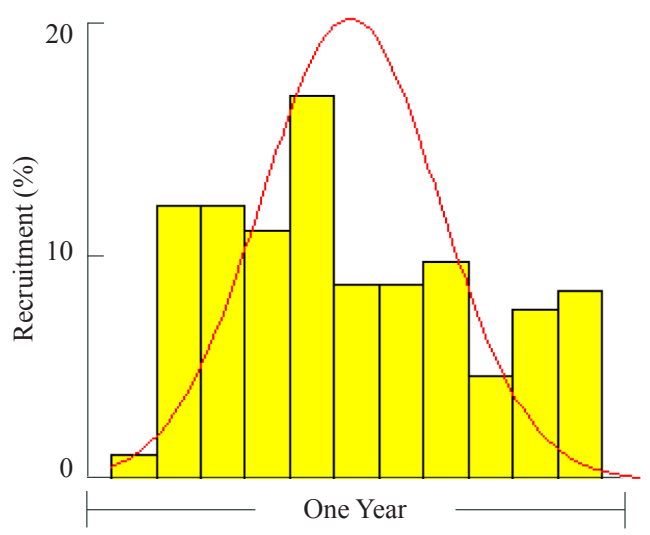

Fig. 3 Computed monthly recruitment pattern of Echinorhinus cf. brucus from south-eastern Arabian Sea for a period of one year.

The relative yield per recruit $(\mathrm{Y} / \mathrm{R})$ and biomass per recruit $(\mathrm{B} / \mathrm{R})$ determined as a function of $\mathrm{L}_{\mathrm{c}} / \mathrm{L}_{\infty}$ and $\mathrm{M} / \mathrm{K}$ (Fig. 4). In the yield contours (isopleth diagram), $\mathrm{L}_{\mathrm{c}} / \mathrm{L}_{\infty}, \mathrm{E}$ and $\mathrm{M} / \mathrm{K}$ ratio are compared to determine the fishing status and the stock can be classified into four quadrants (Pauly and Soriano, 1986). In the present study, with an $\mathrm{L}_{\mathrm{c}} / \mathrm{L}_{\infty}$ of 0.6 and $E$ of 0.56 , the stock belongs to quadrant $\mathrm{C}$ which implies that large specimens are caught at higher efforts. E. cf. brucus fits under this category 
which suggests that the efforts must be stabilised and possibly reduced, as a management measure. The $\mathrm{M} / \mathrm{K}$ was estimated as 1.4 . The $\mathrm{M} / \mathrm{K}$ ratio is found to be constant among the closely related species and the $\mathrm{M} / \mathrm{K}$ ratio in fishes generally falls within the limit of 1.5-2.5 (Beverton and Holt, 1959). The results of the present study reinforce the need for monitoring the fishing effort on E. cf. brucus population along the south-west coast of India.
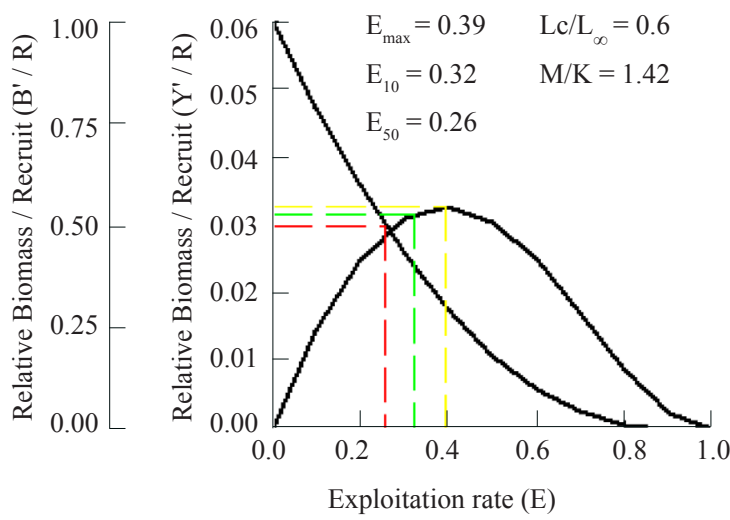

Fig. 4. Stock status of Echinorhinus cf. brucus from southeastern Arabian Sea, using Beverten and Holt's relative $\mathrm{Y} / \mathrm{R}$ analysis

Virtual population analysis (VPA) revealed that all size groups are caught in the fishery and fishing mortality (F) rate increases from $80 \mathrm{~cm}$ TL (Fig. 5). The fishing mortality (F) increases to maximum of $0.20-0.23$ at 221-230 cm TL, subsequently decreases to $0.18-0.19$ at $261-270 \mathrm{~cm}$ TL and abruptly increases to $0.26-0.28$ at $291-300 \mathrm{~cm} \mathrm{TL}$. However, for the recruitment size class (45-105 cm TL, 1-3 year class), the average fishing mortality is 0.15 whereas average total mortality is 0.17 suggesting fishing pressure in juveniles are also quite high which lead to growth overfishing. The reason for a sudden increase in F in larger size class is possibly due to larger sized sharks coming as bycatch and are retained in the fishery. Fishing mortality exceeds natural mortality from $224.5 \mathrm{~cm}$ TL onwards. The mean F from the fully recruited groups $(221-320 \mathrm{~cm} \mathrm{TL})$ was 0.28 . There is both growth and recruitment overfishing in E. cf. brucus bycatch fishery in the southern Arabian Sea region and will affect the population turnover rates leading to ecosystem overfishing. This would need a lot of time for recovering from the impact.

In all coastal states of India, fleet sizes currently in operation are greater than the estimated optimum fleet sizes (Sathianandan et al., 2008) and no restriction is imposed on reducing efforts. Therefore, the only means of reducing the fishing pressure will be implementing additional

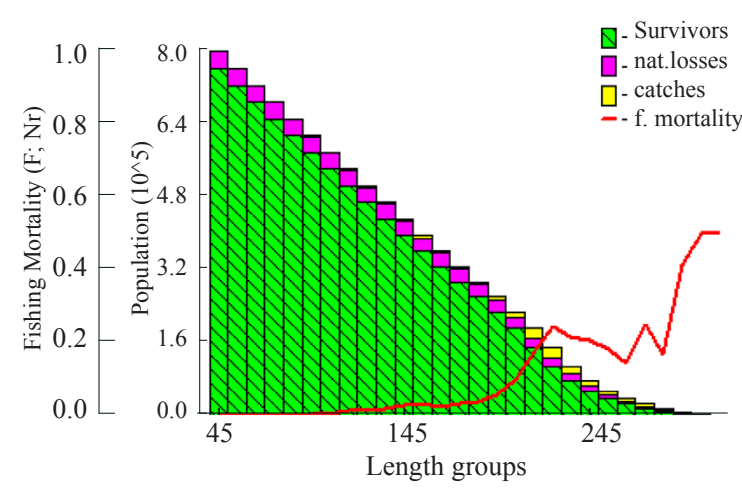

Fig. 5. Length structured VPA analysis of Echinorhinus cf. brucus from south-eastern Arabian Sea, based on current fishing mortality

closed fishing seasons in addition to the existing closed season (June 15 to July 31 for west coast), extending closed seasons, declaring non-fishing zones in coastal and deep sea waters as well as moratorium on entry of new fishing vessels. With the current social and political scenarios in Indian fisheries sector, advocating most of the management efforts are becoming tough unless there is a strong political will to implement the same.

On a long-term basis, reducing $\mathrm{L}_{\mathrm{c}} / \mathrm{L}_{\infty}$ is suggested so that length at first capture can be increased from the current level and effort reduction. As a precautionary measure in fishery management, the Government of Kerala has implemented a minimum legal size (MLS) for utilisation/ trade of important commercially exploited species and this could also be expanded to include commonly exploited long-lived fish species that occur as bycatch species as well. However, effective implementation of MLS in a tropical multispecies fishery is a management challenge that requires enforcement of mesh size regulations, demarcation of spawning/breeding/nursery grounds and implementation of no-take zones in participatory approach.

Bycatch and their utilisation for commercial purposes is a major challenge in the Indian fisheries sector. With depleting near shore resources, bycatch utilisation and commercialisation can lead to target fishery of commercially lesser important species and juveniles for non-consumption purposes (Lobo et al., 2010). In the recent years. commercial utilisation of consumable fish catch and bycatch has increased (Aswathy and Narayanakumar 2013). In the deep sea shrimp trawl fishery targeting Plesionika spp., Heterocarpus spp., Solenocera spp., Metapenaeopsis spp. and Aristeus spp., operating at depths from 200-700 m in southern coasts of India, huge quantity of $E$. cf. brucus are being landed as bycatch along with several other 
deep sea sharks and utilised (Akhilesh et al., 2011; Akhilesh and Ganga, 2013). Available catch records and preliminary evidence from the current study shows that E. cf. brucus in the deep waters off southern India are under high fishing pressure (Akhilesh et al., 2013), however it is a well-known fact that for most deep sea bycatch taxa only limited time series data on catch and effort is available in India. Low productivity and high exploitation of deep sea fauna are a matter of high concern (Norse et al., 2012). Generating information on Data Deficient groups are important for reducing extinction risk by management interventions. Limited information from bramble shark fisheries has indicated that serious harvest related declines have taken place in parts of the north-east Atlantic Ocean (Quero and Cendrero, 1996; Quero, 1998). Similarly, Ali and Sinan (2014) showed that targeted fishery for the deep sea gulper sharks in Maldives led to rapid declines within four years of exploitation. Similarly, in the southern coasts of India, targeted deep sea shark fishery expanded rapidly, due to demand for liver oil and within few years, fishery landings declined in number and size leading to non-profitable venture and closure of fishery, but still bycatch continues. Gibson et al. (2008) reported that the reduced availability of stocks, rather than falling market values, as the major reason for deep sea shark fisheries becoming unprofitable. which is partially applicable to south Indian deep sea shark fishery too. The market demand for shark meat is quite high in southern India. The expanding fisheries and their shark bycatch provides reasonable incentives for bringing the deep sea sharks too, at whatever sizes and quantity caught.

Trends in exploitation can be used as a proxy to improve our understanding of the population status. To achieve sustainable fishery through rational exploitation, it is essential to have reliable data on population parameters and life history traits of exploited taxa. Considering the highly vulnerable nature of deep sea chondrichthyans, it is very much essential to estimate basis of fisheries management science such as the growth, maturity, population parameters and mortality for effective management and supporting policy decisions. Studies from elsewhere have shown that slow growing species can be harvested sustainably with good science-based management measures and catch restrictions limiting to a portion of the stock (Rago and Sosebee, 2009; Wallace et al., 2009; Simpfendorfer and Dulvy, 2017). However, it is known that length-based growth and population models have limitations (Laslett et al., 2004; Pardo et al., 2013) due to natural variability in productivity factor, changes in fishing systems and operation details. Notwithstanding these limitations, precautionary approaches can be made based on the current preliminary results and available information. In most tropical countries, fisheries management policies give little priority for certain categories of fishes such as juveniles exploited/low quality high value fishes used for fishmeal and deep sea fishes. Deep water bycatch species often fall in category of high conservation concern. Detailed studies (fisheries independent and dependent) on deep water fauna and their ecological characters in addition to continuous monitoring of expanding deep sea fisheries in tropical countries are required for developing management strategies as well as to reduce the extinction risks

\section{Acknowledgements}

Authors are grateful to the fishers, traders, merchants of Cochin Fisheries Harbour, Kerala for the help and support. Thanks to Hashim, Shanis, Manju and Beni during the surveys and support in the laboratory. MoESCMLRE is acknowledged for financial assistance during the study period.

\section{References}

Akhilesh, K. V., Ganga, U., Pillai, N. G. K., Vivekanandan, E., Bineesh, K. K., Shanis, C. P. R. and Hashim, M. 2011. Deep sea fishing for chondrichthyan resources and sustainability concerns - a case study from south-west coast of India. Ind. J. Geo-Mar Sci., 40: 347-35.

Akhilesh, K. V. and Ganga, U. 2013. Note on the targeted fishery for deep-sea oil sharks at Cochin Fisheries Harbour. Mar. Fish. Infor. Serv., T\&E Ser., 218: 22-23.

Akhilesh, K. V., Bineesh, K. K., White, W. T., Shanis, C. P. R., Hashim, M., Ganga, U. and Pillai, N. G. K. 2013. Catch composition, reproductive biology and diet of the bramble shark Echinorhinus brucus (Squaliformes: Echinorhinidae) from the south-eastern Arabian Sea. J. Fish Biol., 83(5): 1112-1127. https://doi.org/10.1111/ jfb.12201.

Ali, K. and Sinan, H. 2014. Shark ban in its infancy: Successes, challenges and lessons learnt J. Mar. Biol. Ass. India, 56: 34-40. doi: 10.6024/jmbai.2014.56.1.01750s-05.

Aswathy, N. and Narayanakumar, R.2013. Economic analysis of fishmeal plants in Uttara Kannada District, Karnataka. Mar. Fish. Inf. Serv. T\&E Ser., 217: 5-7.

Avsar, D. 2001. Age, growth, reproduction and feeding of the spurdog (Squalus acanthias Linnaeus, 1758) in the Southeastern Black Sea. Est. Coast. Shelf Sci., 52: 269-278. DOI: $10.1006 /$ ecss.2000.0749.

Barrul, J. and Mate, I. 1996. The sharks of the Catalan countries. Portic, Barcelona, Spain.

Beverton, R. J. H. and Holt, S. J. 1959. A review of the life span and mortality rates of fish in nature and their relation to growth and other physiological characteristics. CIBA Foundation Symposium The life span of animals Colloquia on Ageing, 5: 142-180. 
Branstetter, S. and Musick, J. A. 1994. Age and growth estimates for the sand tiger in the North-western Atlantic Ocean. Tran. Amer. Fish. Soc., 123: 242-254. https://doi. org/10.1577/1548-8659(1994)123<0242:AAGEFT>2.3. $\mathrm{CO} ; 2$.

Branstetter, S. 1987. Age and growth validation of newborn sharks held in laboratory aquaria, with comments on the life history of the Atlantic sharpnose shark, Rhizoprionodon terraenovae. Copeia, 291-300. DOI: 10.2307/1445764.

Cailliet, G. M. 1990. Elasmobranch age determination and verification: an updated review in Elasmobranchs as Living Resources. In: Pratt, W. S., Gruber, Jr., S. H. and Taniuchi, T. (Eds.), Advances in the biology, ecology, systematics and the status of the fisheries, NOAA Tech. Rep., 90: 157-165.

Cailliet, G. M. and Goldman, K. J. 2004. Age determination and validation in chondrichthyan fishes. In: Carrier, J. C. Musick, J. A. and Heithaus, M. R. (Eds), Biology of sharks and their relatives. CRC press. USA, p. 399-447.

Clarke, M. W., Kelly, C. J., Connolly, P. L. and Molloy, J. P. 2003. A life history approach to the assessment and management of deepwater fisheries in the North-east Atlantic. J. Northw. Atl. Fish. Sci., 31: 401-411.

Coelho, R. and Erzini, K. 2005. Length at first maturity of two species of lantern sharks (Etmopterus spinax and Etmopterus pusillus) off southern Portugal. J. Mar. Biol. Ass. U. K., 85(5): 1163-1165. DOI: 10.1017/ S0025315405012245.

Compagno, L. J. V. 1984. FAO species catalogue. Vol. 4, Part 2: Sharks of the world. FAO Fish. Synop., 125: 173.

Compagno, L. J. V., Dando, M. and Fowler, S. 2005. A field guide to sharks of the world. Harper Collins Publishing Ltd., London, UK, 368 pp.

Cortes, E. 2000. Life history patterns and correlations in sharks. Rev. Fish. Sci., 8(4): 299-344.

Devine, J. A., Baker, K. D. and Haedrich, R. L. 2006. Fisheries: deep-sea fishes qualify as endangered. Nature, 439: 29.

Ducatez, S. 2019. Which sharks attract research? Analyses of the distribution of research effort in sharks reveal significant non-random knowledge biases. Rev. Fish Biol. Fish., 29(2): 355-367. DOI:10.1007/s11160-019-09556-0.

Dulvy, N. K and Forrest, R. E. 2010. Life histories, population dynamics and extinction risks. In: Carrier, J. C., Musick, J.A. and Heithaus, M. R. (Eds.), Chondrichthyans - Sharks and their relatives II: Biodiversity, adaptive physiology and conservation, $1^{\text {st }}$ edn. CRC Press, Taylor and Francis Group, London, UK, p. 635-667.

Dulvy, N. K., Fowler, S. L., Musick, J. A., Cavanagh, R. D., Kyne, P. M., Harrison, L. R., Carlson, J. K., Davidson, L. N. K., Fordham, S. V., Francis, M. P., Pollock, C. M., Simpfendorfer, C. A., Burgess, G. H., Carpenter, K. E., Compagno, L. J. V., Ebert, D. A., Gibson, C., Heupel,
M. R., Livingstone, S. R., Sanciangco, J. C., Stevens, J. D., Valenti, S. and White, W. T. 2014. Extinction risk and conservation of the world's sharks and rays. eLife, 3: e00590. DOI: 10.7554/eLife.00590.p.1-34.

Fernando, D., Bown, R. M. K., Tanna, A., Gobiraj, R., Ralicki, H., Jockusch, E. L., Ebert, D. A., Jensen, K. and Caira, J. N. 2019. New insights into the identities of the elasmobranch fauna of Sri Lanka. Zootaxa, 4585(2): 201-238. DOI: https://doi.org/10.11646/zootaxa.4585.2.1.

García, V. B., Lucifora, L. O. and Myers, R. A. 2008. The importance of habitat and life history to extinction risk in sharks, skates, rays and chimaeras. Proc. R. Soc. Lond., B, Biol. Sci., 275: 83-89. doi: 10.1098/rspb.2007.1295.

Gayanilo, F. C., Sparre, P. and Pauly, D. 2005. The FAOICLARM stock assessment tools II (FiSAT II). User's guide. Revised Version, FAO Computerised Information Series (Fisheries), vol. 8, Food and Agriculture Organisation, Rome, Italy, $190 \mathrm{pp}$.

Gayanilo, F. C. Jr. and Pauly, D. 1997. The FAO-ICLARM Stock Assessment Tool (FiSAT) Reference manual. FAO Computerised Information Series (Fisheries), vol. 8, Food and Agriculture Organisation Rome, Italy, $262 \mathrm{pp}$.

Gibson, C., Valenti, S. V., Fordham, S. V. and Fowler, S. L. 2008. The conservation of North-east Atlantic Chondrichthyans: Report of the IUCN Shark Specialist Group. North-east Atlantic Red List Workshop.viji + 76 pp.

Graham, K. J., Andrew, N. L. and Hodgson, K. E. 2001. Changes in relative abundance of sharks and rays on Australian South-east fishery trawl grounds after twenty years of fishing. Mar. Fresh. Res., 52: 549-561. DOI:10.1071/ MF99174.

Gulland, J. A. 1971. The fish resources of the ocean. Fishing News (Books), West Byfleet, UK, 255 pp.

Henderson, A. C., Mcllwain, J. L., Al-Oufi, H. S. and Al-Sheili, S. 2007. The Sultanate of Oman shark fishery: species composition, seasonality and diversity. Fish. Res., 86: 159-168. DOI: 10.1016/j.fishres.2007.05.012.

Henderson, A. C., Reeve, A. J., Jabado, R. W. and Naylor, G. J. P. 2016. Taxonomic assessment of sharks, rays and guitarfishes (Chondrichthyes: Elasmobranchii) from south-eastern Arabia, using the NADH dehydrogenase subunit2(NADH2)gene.Zool.J.Linn.Soc., 176(2): 399-442. https://doi.org/10.1111/zoj.12309.

Hutchings, J. A. 2002. Life histories of fish. In: Hart, P. J. B. and Reynolds, J. D (Eds.), Handbook of fish biology and fisheries, vol. 1. Blackwell Science, Oxford, UK, p. 149-174.

Jabado, R. W., Kyne, P. M., Pollom, R. A., Ebert, D. A., Simpfendorfer, C. A., Ralph, G. M and Dulvy, N. K. 2017. The conservation status of sharks, rays and chimaeras in the Arabian Sea and Adjacent Waters. Environment Agency, Abu Dhabi, UAE and IUCN Species Survival Commission Shark Specialist Group, Vancouver, Canada, 236 pp. 
Jabado, R. W., Kyne, P. M., Pollom, R. A., Ebert, D. A., Simpfendorfer, C. A., Ralph, G. M., Al Dhaheri, S. S., Akhilesh, K. V., Ali, K., Ali, M. H., Al Mamari, T. M. S., Bineesh, K. K., El Hassan, I. S., Fernando, D., Grandcourt, E. M., Khan, M. M., Moore, A. B. M., Owfi, F., Robinson, D. P., Romanov, E., Soares, A., Spaet, J. L. Y., Tesfamichael, D., Valinassab, T. and Dulvy, N. K. 2018. Troubled waters: Threats and extinction risk of the sharks, rays and chimaeras of the Arabian Sea and adjacent waters. Fish Fish., 19(6): 1043-1062. DOI: 10.1111/faf.12311.

Ketchen, K. S. 1975. Age and growth of dogfish Squalus acanthias in British Columbia waters. J. Fish. Res. Board Can., 32(1): 43-59. DOI: 10.1139/f75-006.

Kumar, R. R., Venu, S., Akhilesh, K. V., Bineesh, K. K. and Rajan, P. T. 2018. First report of four deep-sea chondrichthyans (Elasmobranchii and Holocephali) from Andaman waters, India with an updated checklist from the region. Acta Ichthyol. Piscat., 48(3): 289-301. DOI: 10.3750/AIEP/02336.

Kyne, P. M. and Simpfendorfer, C. A. 2007. A collation and summarisation of available data on deepwater chondrichthyans: biodiversity, life history and fisheries. Report prepared by the IUCN SSC Shark Specialist Group for the Marine Conservation Biology Institute, $37 \mathrm{pp}$.

Kyne, P. M. and Simpfendorfer, C. A. 2010. Deepwater chondrichthyans. In: Carrier, J. C., Musick, J. A. and Heithaus, M. R (Eds.), Sharks and their relatives II: Biodiversity, adaptive physiology and conservation, CRC Press, Boca Raton, Florida, USA, p. 37-114.

Laslett, G. M., Eveson, J. P. and Polacheck, T. 2004. Fitting growth models to length frequency data. ICES J. Mar. Sci., 61(2): 218-230. doi:10.1016/j.icesjms.2003.12.006.

Liu, K. M., Chiang, P. J. and Chen, C. T. 1998. Age and growth estimates of the bigeye thresher shark, Alopias superciliosus, in north-eastern Taiwan waters. Fish. Bull., 96(3): 482-491.

Liu, K. M., Chin, C. P., Chen, C. H. and Chang, J. H. 2015. Estimating finite rate of population increase for sharks based on vital parameters. PLoS ONE, 10(11): e0143008

Lobo, A. S., Balmford, A., Arthur, R. and Manica, A. 2010. Commercialising bycatch can push a fishery beyond economic extinction. Conserv. Lett., 3: 277-285. DOI: 10.1111/j.1755263X.2010.00117.x.

Morato, T., Watson, R., Pitcher, T. J and Pauly, D. 2006. Fishing down the deep. Fish Fish., 7: 24-34. https://doi. org/10.1111/ j.1467-2979.2006.00205.x.

Munro, J. L. and Pauly, D. 1983. A simple method for comparing the growth of fishes and invertebrates. ICLARM Fish Byte, 1(1): 5-6.

Naylor, G. J. P., Caira, J. N., Jensen, K., Rosana, K. A. M., White, W. T. and Last, P. R. 2012. A DNA sequence-based approach to the identification of shark and ray species and its implications for global elasmobranch diversity and parasitology. Bull. Am. Mus. Nat. Hist., 367: 1-262.

Norse, E. A., Brooke, S., Cheung, W. W. L., Clark, M. R., Ekeland, I., Froese, R., Gjerde, K. M., Haedrich, R. L., Heppell, S. S., Morato, T., Morgan, L. E., Pauly, D., Sumaila, R. and Watson R. 2012. Sustainability of deep-sea fisheries. Mar. Policy, 36: 307-320.

Pardo, S. A., Cooper, A. B. and Dulvy, N. K. 2013. Avoiding fishy growth curves. Methods Ecol. Evol., 4(4): 353-360. https://doi.org/10.1111/2041-210x.12020.

Paul, L. 2003. Echinorhinus brucus. The IUCN Red List of Threatened Species 2003: e.T41801A10563978.http://dx.doi. org/ 10.2305/IUCN.UK.2003.RLTS.T41801A 10563978.

Pauly, D. and Soriano, M. L. 1986. Some practical extensions to Beverton and Holt's relative yield-per-recruit model. In: Maclean, J. L., Dizon, L. B. and Hosillos, L. V. (Eds.), Proceedings of the First Asian Fisheries Forum, Asian Fisheries Society, Manila, Philippines, p. 491-496.

Pauly, D. 1979. Theory and management of tropical multispecies stocks: a review with emphasis on the South-east Asian demersal fisheries. ICLARM: Stud. Rev., 1, International Centre for Living Aquatic Resources Management, Manila, Philippines, $35 \mathrm{pp}$.

Pauly, D. 1980. On the interrelationship between natural mortality, growth parameters and mean environmental temperature in 175 fish stocks. J. Cons. Int. Explor. Mer., 39(2): 175-179.

Pauly, D. 1984. Fish population dynamics in tropical waters: A manual for use with programmable calculators. ICLARM Stud. Rev., 8, International Centre for Living Aquatic Resources Management, Manila, Philippines, 325 pp.

Quero, J. C. and Cendrero, O. 1996. Effect of fishing on the ichthyological biodiversity of the Bassin d'Arcachon and the surrounding continental shelf. Cybium, 20: 323-356. https://doi.org/10.1080/11250009809386873.

Quero, J. C. 1998. Changes in the Euro-Atlantic fish species composition resulting from fishing and ocean warming. Ital. J. Zool., 65: 493-499.

Rago, P. J. and Sosebee, K. A. 2009. The agony of recovery: Scientific challenges of spiny dogfish recovery programs In: Gallucci, V. F., McFarlane, G. A. and. Bargman, G. G. (Eds), Biology and management of dogfish sharks. American Fisheries Society, Bethesda, Maryland, USA, p. 343-372.

Sathianandan, T. V., Jayasankar, J., Vivekanandan, E., Narayankumar, R. and Pillai, N. G. K. 2008. Estimates on potential yield and maximum sustainable fleet size for marine fisheries in Kerala. J. Mar. Biol. Ass. India, 50(2): 196-201.

Simpfendorfer, C. A. 1993. Age and growth of the Australian sharpnose shark, Rhizoprionodon taylori, from north 
Queensland, Australia. Env. Biol. Fish., 36: 233-241. DOI: 10.1007/BF00001718.

Simpfendorfer, C. A. and Kyne, P. M. 2009. Limited potential to recover from overfishing raises concerns for deepsea sharks, rays and chimaeras. Env. Cons., 36: 97-103. DOI: $10.1017 / \mathrm{S} 0376892909990191$.

Simpfendorfer, C. A. and Dulvy, N. K. 2017. Bright spots of sustainable shark fishing. Curr. Biol., 27(3): 97-98. doi: 10.1016/j.cub.2016.12.017.

Wallace, S., McFarlane, G., Campana, S. and King, J. R. 2009. Status of spiny dogfish in Atlantic and Pacific Canada. In: Gallucci, V. F., McFarlane, G. A. and Bargmann, G. C.,
(Eds.), Biology and management of spiny dogfish sharks. American Fisheries Society, Bethesda, Maryland,, USA.

Walmsley-Hart, S. A., Sauer, W. H. H. and Buxton, C. D. 1999. The biology of the skates Raja wallacei and R. pullopunctata (Batoidea: Rajidae) on the Agulhas Bank, South Africa. South Afr. J. Mar. Sci., 21: 165-179. DOI: $10.2989 / 025776199784126051$.

Worm, B., Davis, B., Kettermer, L., Ward-Paige, C. A., Chapman, D., Heithaus, M. R., Kessel, S. T. and Gruber, S. H. 2013. Global catches, exploitation rates, and rebuilding options for sharks. Mar. Policy, 40: 194-204. https://doi. org/ 10.1016/j.marpol.2012.12.034. 